\title{
QUANTITATIVE ANALYSIS OF DOCTORAL DISSERTATIONS IN SERBIA AT THE END OF 2019 ON THE TOPIC ARTIFICIAL INTELLIGENCE
}

\author{
Olga Mirković Maksimović ${ }^{1}$
}

DOI: https://doi.org/10.31410/LIMEN.2020.357

\begin{abstract}
The Strategy for the Development of Artificial Intelligence (AI) for the period from 2020 to 2025 has been adopted in Serbia and the strategy proposal states that one of the goals is the development of science and innovation in the field of AI. Some of the indicators being measured are the number of patents as well as the number of published papers in this field. The initial state is currently unknown. The aim of this paper is to establish how many dissertations at which University and faculty have been defended on this topic, who are the most common mentors and members of the commissions. The paper deals with publicly available data of doctoral dissertations in Serbia and makes a quantitative analysis of doctoral dissertations on the topic of AI.
\end{abstract}

Keywords: Artificial intelligence, Doctoral dissertations, Universities in Serbia, Strategy for the development of artificial intelligence.

\section{INTRODUCTION}

7 he paper deals with publicly available data of doctoral dissertations in Serbia (http://nardus.mpn.gov.rs/discover) and a quantitative analysis of doctoral dissertations that had artificial intelligence as their topic. In Serbia, the Strategy for the Development of Artificial Intelligence in the Republic of Serbia for the period from 2010 to 2025 (Ministry of Education, Science and Technological Development, 2019) was adopted and the proposed strategy clearly states that one of the goals is the development of science and innovation in the field of artificial intelligence and its applications. Some of the indicators being measured are the number of patents as well as the number of published papers in this field. The initial state is currently unknown. The aim of this paper is to establish how many dissertations at which University and which faculty were defended on the topic of artificial intelligence, who are the most common mentors and members of the commissions. Thus, we get a list of people who deal with artificial intelligence in Serbia and their distribution among faculties, universities, with the aim of clearly mapping the situation in the field of research of artificial intelligence in Serbia within university academic studies.

\section{QUANTITATIVE ANALYSIS}

By inspecting the public database of defended doctoral dissertations http://nardus.mpn.gov.rs/discover and searching by the phrase "artificial intelligence", we get that the total number of dissertations on the topic of "artificial intelligence" is 324 . However, a detailed review of the metadata of 324 doctoral dissertations as well as key words related to them shows that 82 doctoral dissertations concern artificial intelligence, and most broadly

$1 \quad$ Videobolt, Bulevar Mihajla Pupina 10a, Belgrade, Serbia 
speaking. Due to the lack of a single definition of artificial intelligence and the use of very different approaches in defining artificial intelligence, all doctoral dissertations were taken into account, which included key words such as: artificial neural networks, intelligent networks, intelligent control, model-driven development etc. From the very beginning, artificial intelligence has been multidisciplinary and this can be seen through the fact that doctoral dissertations are present at almost all faculties of the University of Serbia. Artificial intelligence was created as an attempt to answer the question is it possible to simulate and create intelligence in a computer environment - that is why it is inextricably linked to computer science. Artificial intelligence is an attempt to answer the question of whether a computer can perform a task that, when performed by a human being, requires intelligence. Table 1 shows the total number of searches for the phrase "artificial intelligence" after the review of the meaning of the search at all University in Serbia.

Table 1. Total number of searches for the phrase "artificial intelligence" at all University in Serbia.

\begin{tabular}{|c|c|}
\hline & $\begin{array}{c}\text { Number of doctoral dissertations at the } \\
\text { end of 2019 on the AI topic }\end{array}$ \\
\hline University of Belgrade & 39 \\
\hline University of Novi Sad & 25 \\
\hline University of Nis & 6 \\
\hline University of Kragujevac & 7 \\
\hline University of Arts in Belgrade & 1 \\
\hline University of Business Academy in Novi Sad & 2 \\
\hline Alpha BK University & 0 \\
\hline European University & 1 \\
\hline University Signinum & \\
\hline University of Pristina - Kosovska Mitrovica & \\
\hline
\end{tabular}

Table 2 shows the number of doctoral dissertations on the topic of artificial intelligence at the University of Belgrade by faculties.

Table 2. Number of doctoral dissertations on the topic of artificial intelligence at the University of Belgrade by faculties

\begin{tabular}{|c|c|}
\hline & $\begin{array}{c}\text { Number of doctoral dissertations at the } \\
\text { BU by faculties }\end{array}$ \\
\hline Faculty of Organizational Sciences & 13 \\
\hline Faculty of Electrical Engineering & 6 \\
\hline School of Mechanical Engineering & 5 \\
\hline Faculty of Philosophy & 3 \\
\hline School of Civil Engineering & 3 \\
\hline Pharmaceutical University & 3 \\
\hline Faculty of Transportation & 2 \\
\hline Faculty of Technology and Metallurgy & 2 \\
\hline Faculty of Economics & 1 \\
\hline Technical Faculty Bor & 1 \\
\hline
\end{tabular}

Table 3 shows the number of doctoral dissertations on the topic of artificial intelligence at the University of Novi Sad by faculties. 
Table 3. Number of doctoral dissertations on the topic of artificial intelligence at the University of Novi Sad by faculties

\begin{tabular}{|c|c|}
\hline & $\begin{array}{c}\text { Number of doctoral dissertations at the } \\
\text { University of Novi Sad by faculties }\end{array}$ \\
\hline Faculty of Technical Sciences & 16 \\
\hline Technical Faculty "Mihailo Pupin" Zrenjanin & 5 \\
\hline Faculty of natural sciences & 3 \\
\hline Faculty of Technology & 1 \\
\hline
\end{tabular}

Table 4 shows the number of doctoral dissertations on the topic of artificial intelligence at the University of Niš by faculties.

Table 4. Number of doctoral dissertations on the topic of artificial intelligence at the University of Niš by faculties

\begin{tabular}{|c|c|}
\hline & $\begin{array}{c}\text { Number of doctoral dissertations at the } \\
\text { University of Niš by faculties }\end{array}$ \\
\hline School of Mechanical Engineering & 2 \\
\hline Faculty of Electronic Engineering & 2 \\
\hline Faculty of Economics & 1 \\
\hline Faculty of Technology Leskovac & 1 \\
\hline
\end{tabular}

Table 5 shows the number of doctoral dissertations on the topic of artificial intelligence at the University of Kragujevac by faculties.

Table 5. Number of doctoral dissertations on the topic of artificial intelligence at the University of Kragujevac by faculties

\begin{tabular}{|c|c|}
\hline & $\begin{array}{c}\text { Number of doctoral dissertations at the } \\
\text { University of Kragujevac by faculties }\end{array}$ \\
\hline Faculty of natural sciences & 3 \\
\hline Faculty of Technical Sciences Čačak & 2 \\
\hline Faculty of Engineering & 2 \\
\hline
\end{tabular}

At the University of Business Academy in Novi Sad, at the Faculty of Dentistry, 1 doctoral dissertation on the topic of artificial intelligence was defended. At the University of Alfa BK, Faculty of Information Technology, 2 doctoral dissertations on the topic of artificial intelligence were defended. 1 doctoral dissertation in the mentioned field was defended at the University of Singidunum. At the University of Pristina, Faculty of Technical Sciences, 1 doctoral dissertation was defended.

The first doctoral thesis on the topic of artificial intelligence was defended in 1999 by Raskovic Miodrag, before a commission: Mijajlovic Zarko, Markovic Zoran and Bankovic Dragic at the Faculty of Natural Sciences and Mathematics on the topic: "Some probabilistic logics and their applications in computing".

The figure 1. shows the number of defended doctoral dissertations on the topic of artificial intelligence from 1999 until now. It is evident that in the 21st century, research on the topic of "artificial intelligence" has started to develop more intensively, and that this has resulted in an increased number of defended doctoral dissertations starting from 2012 onwards. 
Figure 1. The number of defended doctoral dissertations on the topic of artificial intelligence from 1999 until end of 2019.

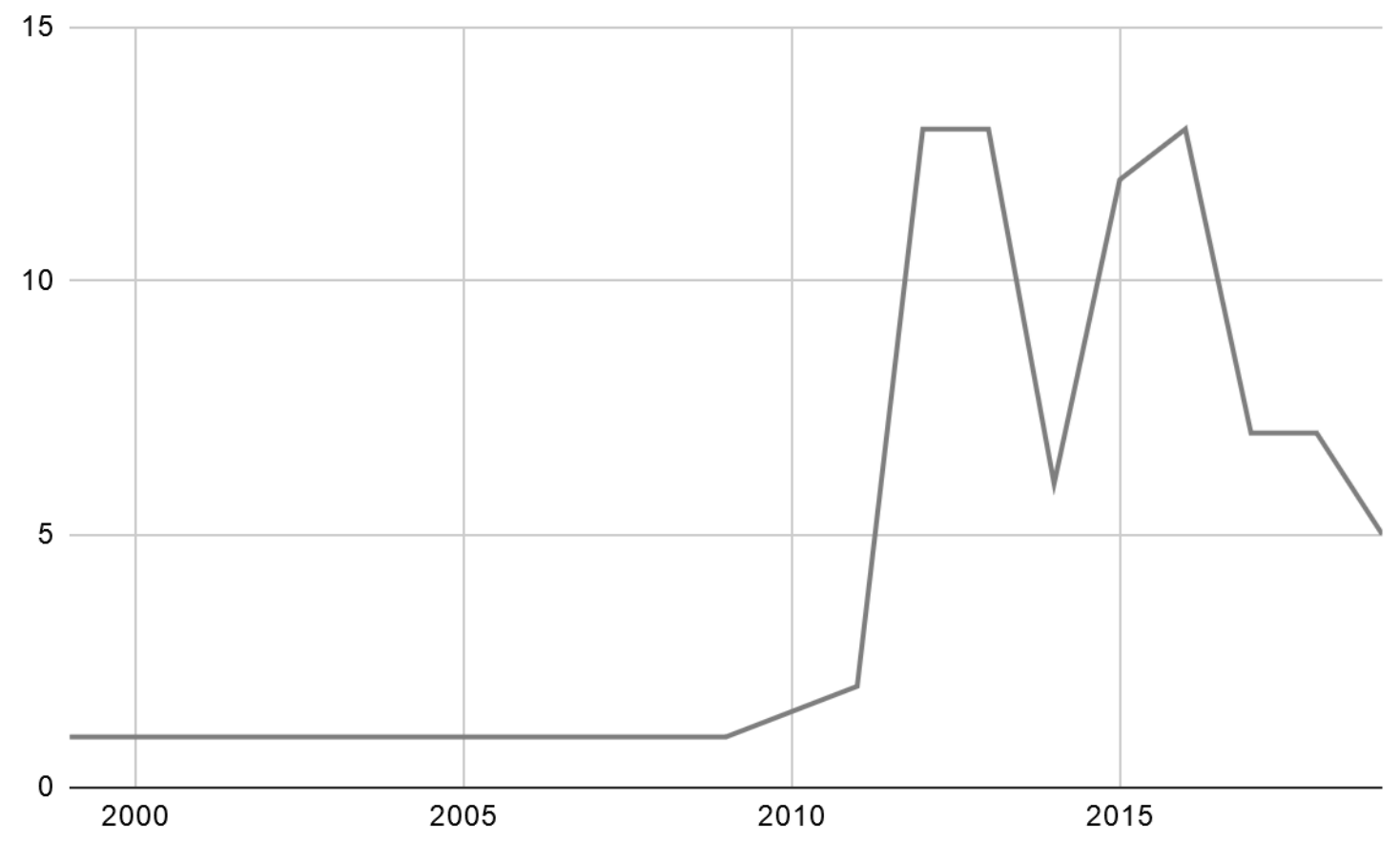

As for mentors, a total of 67 mentors participated. Mentors who have had more than one $\mathrm{PhD}$ student are:

- Suknovic Milija: 4,

- Despotovic-Zrakic Marijana: 2,

- Devedzic Vladan: 2,

- Ivanovic Mirjana: 2,

- Kovac Pavel: 2,

- Miskovic Zoran: 2,

- Vujosevic Mirko: 2,

- Vukadinović Katarina S.: 2.

Eight of them are in charge of 18 doctorates, which make up $22 \%$ of all doctorates on the topic of artificial intelligence. (12\% of mentors covered $22 \%$ of all doctoral theses)

\section{FUTURE RESEARCH DIRECTIONS}

It would be very useful to continue research in this area and see if some of these doctoral dissertations had implementation in industry or business. Also, to see connection between students and industry and see what was their work status and where and how they continue to develop.

\section{CONCLUSION}

In order for Serbia to progress outside of artificial intelligence, it is necessary to intensify scientific research in this area. In recent years, there has been a decline in the number of doctoral dissertations on the topic of artificial intelligence, and it is necessary to increase that 
number in order to build a knowledge base within the University. It would be desirable to return the number of doctoral dissertations at universities to 13. Through networking of mentors and committee members from different faculties and institutes, the first step can be taken. We notice that the number of commission members differs greatly at the University of Belgrade and the University of Novi Sad, where the number of commission members is significantly higher and the base of scientists working on the problem of artificial intelligence is also larger. It is necessary to create and update a unique database of scientists in this field with the aim of networking and joint work on solving the challenges and tasks presented by the proposed strategy for the development of artificial intelligence in the Republic of Serbia for the period from 2010 to 2025. Insight into the tag cloud of keywords makes it clear that the beginnings of development are primarily related to the development of computer science and that other sciences are less involved. This is certainly a trend that needs to be changed in the coming period. According to research (McKinsey \& Company, November 2019): "Global AI Survey: AI proves its worth, but few scale impact" we have the following findings: "Adoption of artificial intelligence (AI) continues to increase, and technology pays off. The findings of the latest McKinsey global survey on this topic show an increase in the percentage of AI use in standard business processes by almost 25 percent. Most executives whose companies have adopted AI report that it has increased revenue in the business areas in which it is used, and 44 percent say AI has reduced costs." Such research indicates that artificial intelligence is now developing more intensively in the economy than in science. In order to make the most of the potentials of artificial intelligence, it is necessary to connect the economy and science in the field of research, testing, and implementation of artificial intelligence. The current system of working on projects within science to a lesser extent recognizes the formal connection between the economy and employees in the economy, and it is necessary to redefine these relations and find the best way of formal organization in order to take the best of both systems.

\section{REFERENCES}

McKinsey \& Company. (November 2019). Global AI Survey: AI proves its worth, but few scale impact. North America: McKinsey \& Compan.

Milosavljević, M. (2015). Veštačka intelgencija. Beograd: Univerzitet Singidunum.

Ministarstvo prosvete, nauke i tehnološkog razvoja. (2019, Novembar). Ministarstvo prosvete, nauke $i$ tehnološkog razvoja. Retrieved from http://www.mpn.gov.rs/wpcontent/uploads/2019/11/1-Nacrt-strategije-razvoja-ve\%C5\%A1ta\%C4\%8Dkeinteligencije-u-Republici-Srbiji-za-period-2020.-2025.-godine.pdf. 